\title{
Field dissipation of prometryn, oxyfluorfen and imazethapyr in Mollisol and Vertisol soils ${ }^{1}$
}

\author{
José A. Dumas ${ }^{2}$, Nelson Semidey ${ }^{3}$, Carmen Cacho ${ }^{4}$ \\ and Priscila Casanova ${ }^{5}$
}

J. Agric. Univ. P.R. 92(3-4):183-195 (2008)

\begin{abstract}
Dissipation rate of prometryn, oxyfluorfen and imazethapyr was estimated in the Mollisol San Antón and the Vertisol Fraternidad soil series, both soils from the south semi-arid coastal region of Puerto Rico. The study was carried out in two consecutive years. The herbicides were applied one day after seeding pigeon peas at Juana Díaz (San Antón soil series) and Lajas (Fraternidad soil series) Agricultural Experiment Substations. Herbicide rates were $2.24,0.28$ and $0.070 \mathrm{~kg}$ ai/ha for prometryn, oxyfluorfen and imazethapyr, respectively. Soil samples at $15-\mathrm{cm}$ depth were collected at 0 , $28,56,112$ and 168 days after application. Field half-lives between 2 and 43 , 31 and 88 , and 19 and 46 days were found for prometryn, oxyfluorfen and imazethapyr, respectively. Substantial dissipation rate variability for above mentioned herbicides has been shown to occur within the soil and year treatments. These findings suggest very short and variable persistence for the three herbicides in both soils under a tropical climate.
\end{abstract}

Key words: prometryn, imazethapyr, oxyfluorfen, tropics, field dissipation, persistence

\section{RESUMEN}

Disipación de prometrina, oxyfluorfen e imazethapyr en suelos Mollisols y Vertisols

La disipación de prometrina, oxifluorfen e imazetapyr se estimó en el Mollisol San Antón y el Vertisol Fraternidad en la región semiárida de la costa sur de Puerto Rico. El estudio se llevó a cabo durante dos años consecutivos. Los herbicidas se aplicaron un día después de la siembra de gandules

${ }^{1}$ Manuscript submitted to Editorial Board 19 June 2007.

${ }^{2}$ Chemist, Department of Crop Protection, Agricultural Experiment Station, University of Puerto Rico, 1193 Calle Guayacán, Jardín Botánico Sur, San Juan, PR 00926-1118. Telephone: (787)767-9705 x 2131 (voice); Fax: (787)753-2712; Email: jose_dumas@eea.uprm.edu

${ }^{3}$ Weed Scientist (retired), Department of Crop Protection, Agricultural Experiment Station, Lajas, P.R.

${ }^{4}$ Former Laboratory Technician, Central Analytical and Pesticide Laboratories, Agricultural Experiment Station.

${ }^{5}$ Laboratory Technician, Central Analytical and Pesticide Laboratories, Agricultural Experiment Station. 
en las Subestaciones Experimentales de Juana Díaz (serie San Antón) y Lajas (serie Fraternidad). Los herbicidas se aplicaron a razón de 2.24, 0.28 y $0.07 \mathrm{~kg}$ ia/ha para prometrina, oxifluorfen e imazethapyr, respectivamente. Se tomaron muestras de suelo a $0,28,56,112$ y 168 días después de la aplicación. Los tiempos de vida media en el campo fueron entre 2 y 43,31 y 88 , y 19 y 46 días para prometrina, oxifluorfen e imazethapyr, respectivamente. Hubo variabilidad sustancial en la velocidad de disipación de los herbicidas entre los suelos y los años de muestreo para los herbicidas estudiados. Estos hallazgos sugieren una persistencia corta y variable en ambos suelos en climas tropicales.

Palabras clave: prometrina, imazethapyr, oxifluorfen, trópico, disipación, persistencia

\section{INTRODUCTION}

Herbicides are used to maintain high agricultural production at minimal cost with minimal threat to the environment. Their effectiveness will depend on the magnitude of their soil sorption, climate and persistence. Soil sorption and persistence will depend on soil type and the chemical and physical characteristics of the herbicide. Therefore, the physical and chemical properties of the herbicides must be considered when one is evaluating their sorption and persistence (Oliveira et al., 2001) and their leaching potential (Paraíba et al., 2003). Several herbicides such as prometryn $\left(N^{2}, N^{4}\right.$-di-isopropyl-6-methylthio-1,3,5-triazine-2,4-diamine), oxyfluorfen (2-chloro$\alpha, \alpha, \alpha$-trifluoro-p-tolyl 3-ethoxy-4-nitrophenyl ether) and imazethapyr [5-ethyl-2-(4-isopropyl-4-methyl-5-oxo-4,5-dihydroimidazol-1-H-2-yl)- nicotinic acid] are used in economically important crops in the tropics. Prometryn, oxyfluorfen and imazethapyr are selective herbicides for annual grasses and broadleaf weeds. A variety of crops, including cotton and celery, are tolerant to prometryn; tolerant to oxyfluorfen are vegetables, fruits, cotton, and ornamentals; and to imazethapyr, soybeans, peanuts, dry and edible beans, peas, alfalfa and imidazolinone resistant/tolerant corn. These herbicides belong to major chemical families, and their physical and chemical properties are quite different. Both the chemical and physical properties are important determinants of transport and persistence of herbicides in the environment.

The water solubility and low soil sorption of some herbicides can result in their movement and contamination of sites distant from their initial uses, all of which poses serious threats to water quality in some settings. Herbicides frequently found at non-targeted sites have persistence and mobility between moderate and high, such as some striazine herbicides. Soil type, microbial activity, organic matter content and climatic conditions have a strong influence on the half-life of pesticides (Helling, 1971; Levanon et al., 1994). Because of the contin- 
uous use of herbicides in tropical areas there is a need to learn about their transport and persistence under field conditions. It is most important to study herbicide persistence under the climate and type of soil where it will be applied. However, most herbicide persistence studies have been done in temperate climates; few in the tropics (Oliveira et al., 2001). Temperature is an important climatic factor in controlling the retention and dissipation of a pesticide by soils ( $\mathrm{Li}$ et al., 1996; Oliveira et al., 2001). Therefore, in the tropics the temperature higher than that in temperate climates must affect the dissipation rate of the herbicides. In the temperate climates low dissipation rates have been reported for oxyfluorfen, prometryn and imazethapyr (Ying and Williams, 2000; Loux et al., 1989; WSSA, 1989). The low dissipation of the above mentioned herbicides is due to the soil's activities, chemical and biological, which tend to decrease in the temperate zones. Herbicide transport, persistence and fate are dependent upon physical and chemical processes and climatic conditions (Paraíba et al., 2003). A number of studies have shown a faster degradation rate of pesticides in the tropics (Laabs et al., 2002; Liu and Santiago, 1991) than the rate found in temperate climates (Laabs et al., 2002).

The purpose of this study was to compare the field persistence of three herbicides: the substituted s-triazine prometryn, the diphenyl ether oxyfluorfen, and the imidazoline imazethapyr in a Mollisol and in a Vertisol, both tropical soils from Puerto Rico.

\section{MATERIALS AND METHODS}

\section{Field plots}

Soils selected for the study were Mollisol San Antón (Juana Díaz) and Vertisol Fraternidad (Lajas), both of which are fertile soils from the southern semi-arid coastal region of Puerto Rico. The San Antón soil (SA) at Juana Díaz is a fine loamy, mixed, superactive, isohyperthermic Cumulic Haplustolls, whereas the Fraternidad soil (F) at Lajas is a fine smectitic, isohyperthermic Typic Haplusterts. Field studies were conducted for two consecutive years, 1995 (SA/1 and F/1) and $1996(\mathrm{SA} / 2$ and $\mathrm{F} / 2)$ in the same experimental area at the Lajas and Juana Díaz Agricultural Experiment Substations. Both years pigeon pea (Cajanus cajan L.) cv. Kaki was planted in July at both substations. Prometryne $\left(N^{2}, N^{4}\right.$-di-isopropyl-6-methylthio-1,3,5-triazine2,4-diamine), oxyfluorfen (2-chloro- $\alpha, \alpha, \alpha$-trifluoro-p-tolyl 3-ethoxy-4nitrophenyl ether) and imazethapyr [5-ethyl-2-(4-isopropyl-4-methyl5-oxo-4,5-dihydroimidazol-1-H-2-yl)- nicotinic acid] were applied pre- 
emergence to pigeon pea at $2.24,0.28$, and $0.070 \mathrm{~kg}$ ai/ha, respectively, one day after seeding. The herbicides were applied with a $\mathrm{CO}_{2}-$ pressurized sprayer calibrated to deliver $165 \mathrm{~L} / \mathrm{ha}$ aqueous solution. The expected theoretical concentrations (SETC) of herbicide in the top soil ( $15 \mathrm{~cm}$ depth) were $1.54,0.048$ and $0.19 \mathrm{mg} / \mathrm{kg}$ for prometryn, oxyfluorfen and imazethapyr, respectively. The SETC was calculated by using a bulk density of $1 \mathrm{~g} / \mathrm{ml}$ for both soils and pesticides at the above mentioned rates. Plots consisted of twelve rows $6.1 \mathrm{~m}$ long and $0.91 \mathrm{~m}$ apart. An untreated control plot was included in each field experiment. Treatments were arranged in a randomized complete block design, with four replications.

\section{Soil sampling}

Four soil samples were collected from each plot at 15 -cm depth at 0 , 28, 56, 112 and 168 days after herbicide application. Soil samples were spread over Kraft paper and air-dried for a period no longer than one week. Samples were then sieved to $2 \mathrm{~mm}$, thoroughly mixed, placed in plastic bags and stored at $-20^{\circ} \mathrm{C}$ until residue analysis.

\section{Chemical Analysis}

Organic matter content was quantified by the Walkley-Black modified method (Nelson and Sommers, 1996), and particle size by the hydrometer method. Soil $\mathrm{pH}$ was measured in slurries prepared in a soil/ water ratio (1:2). Cation-exchange capacity was determined with the ammonium acetate method (Sumner and Miller, 1996). Pesticide analytical standards were purchased from Chem Service Corporation (West Chester, PA) .

All organic solvents used for this study were either pesticide grade or residue grade and purchased from Baker Corporation (Phillipsburg, $\mathrm{NJ})$. The C-18 silica gel and the quaternary ion exchange SPE cartridges were purchased from J.T. Baker (Phillipsburg, NJ). The trimethylanilinium hydroxide (TMAH) for methylation was obtained from Supelco Co.

\section{Prometryn and oxyfluorfen extraction}

Twenty-five grams of the air-dried soil sample was placed in a 125$\mathrm{ml}$ Erlenmeyer flask with $100 \mathrm{ml}$ of an acetonitrile: water ( $9: 1$ by volume) solution, refluxed for one hour and then vacuum-filtered through

\footnotetext{
${ }^{6}$ Trade names in this publication are used only to provide specific information. Mention of a trade name does not constitute a warranty or endorsement of equipment or materials by the Agricultural Experiment Station.
} 
Whatman No 1 filter paper. Seventy-five milliliters of the sample solution was transferred to a $125-\mathrm{ml}$ separatory funnel, $20 \mathrm{ml}$ of methylene chloride added, and the stoppered funnel was shaken vigorously for 30 seconds. The layers were allowed to separate, and the aqueous layer was drawn into a beaker; the aqueous phase was extracted two more times. The combined organic extract fractions were dried over a $\mathrm{Na}_{2} \mathrm{SO}_{4}$ bed, transferred to a $250-\mathrm{ml}$ round-bottom flask to concentrate in a vacuum rotary evaporator at room temperature; then the remaining liquid was evaporated to dryness with a gentle flux of nitrogen. The residue was dissolved in $2 \mathrm{ml}$ of $10 \%$ ethyl ether-hexane mixture and transferred to a 3-ml C18 silica gel SPE cartridge previously conditioned with $3 \mathrm{ml}$ of $30 \%$ ethyl ether-hexane followed by $6 \mathrm{ml}$ of $10 \%$ ethyl ether-hexane. The sample vial was washed with $2 \mathrm{ml}$ of $10 \%$ ethyl ether-hexane and the resulting solution added and passed through the SPE cartridge. The cartridge was eluted with three 10-ml portions of $30 \%$ ethyl ether-hexane. The organic phase was collected in a $30-\mathrm{ml}$ calibrated test tube, evaporated to $10 \mathrm{ml}$ under a gentle nitrogen stream, and stored at $-20^{\circ} \mathrm{C}$ until analysis.

\section{Imazethapyr extraction}

Imazethapyr was extracted according to a modified procedure developed by American Cyanamid Company (Curran et al., 1992). The herbicide was extracted from soil by mixing $40 \mathrm{~g}$ of the air-dried soil with $150 \mathrm{ml}$ of $0.5 \mathrm{M} \mathrm{NaOH}$ for one hour in a reciprocating shaker. The sample was centrifuged for $10 \mathrm{~min}$ at $2,000 \mathrm{rpm}$ and the supernatant decanted. The soil was suspended with $40 \mathrm{ml}$ of methanol, shaken for 5 $\mathrm{min}$, and centrifuged for $5 \mathrm{~min}$ at $2,000 \mathrm{rpm}$. The methanol and $\mathrm{NaOH}$ supernatants were combined, and the $\mathrm{pH}$ of the solution was adjusted to 2 with $6 \mathrm{M} \mathrm{HCl}$ in order to precipitate out the humic acid fraction. The sample was centrifuged for $5 \mathrm{~min}$ at $2,000 \mathrm{rpm}$. The methanol$\mathrm{NaOH}$ supernatant was decanted and filtered through a Buchner funnel, then poured into a separatory funnel and shaken for $30 \mathrm{~s}$ with 200 $\mathrm{ml}$ of dichloromethane. The lower phase was collected and the procedure repeated with an additional $100 \mathrm{ml}$ of dichloromethane. The combined dichloromethane extracts were evaporated to dryness at $35^{\circ} \mathrm{C}$ in a rotary evaporator.

A quaternary amine ion exchange cartridge was prepared by elution with $10 \mathrm{ml}$ methanol followed by $10 \mathrm{ml}$ distilled water. Imazethapyr residues were re-suspended in $1 \mathrm{ml}$ methanol and washed through the above described conditioned cartridge with $24 \mathrm{ml}$ of distilled water. This procedure was followed by adding $15 \mathrm{ml} 0.05 \mathrm{M} \mathrm{HCl}$, and eluates were combined. Twenty milliliters of water was added and the solution 
poured in a separatory funnel and partitioned first with $100 \mathrm{ml}$, followed with $50 \mathrm{ml}$, of dichloromethane. The dichloromethane phases were combined, evaporated to dryness, re-suspended in $50 \mathrm{ml}$ methanol and evaporated to dryness again. Imazethapyr residues were transferred to a 2-ml volumetric flask with pesticide grade acetone, methylated with $0.1 \mathrm{ml}$ of TMAH and then analyzed by gas chromatography.

\section{Gas chromatography}

Sample analysis was conducted with a Shimadzu 17A GC-flame thermionic detector equipped with a $30-\mathrm{m} \times 0.25-\mathrm{mm}$ I.D. $(\mathrm{df}=0.1 \mathrm{~mm})$ DB-5 column ( $\mathrm{J} \& \mathrm{~W}$ Scientific, Folsom, CA). The injection mode used was splitless at a temperature of $250^{\circ} \mathrm{C}$, and the detectors were set at $300^{\circ} \mathrm{C}$. An auto injector was used to inject $1 \mu \mathrm{l}$ of sample in splitless mode. The oven temperature started at $60^{\circ} \mathrm{C}$ and was programmed at $40^{\circ} \mathrm{C} / \mathrm{min}$ up to $230^{\circ} \mathrm{C}$. Throughout the run the carrier gas (helium) was maintained at $2.1 \mathrm{ml} / \mathrm{min}$. Pesticide concentrations were calculated by external calibration curves.

\section{Pesticide Half-Life}

To determine field half lives of herbicides we used a first order kinetic model. This model was adequate for describing herbicide dissipation in this study. The first order kinetic equations 1 and 2 were used for this purpose.

$$
\ln [\mathrm{H}]=\ln [\mathrm{H}]_{0}-\mathrm{kt}
$$

Where $[\mathrm{H}]=$ concentration of the herbicide $\mathrm{H}, \mathrm{t}=$ time, and $\mathrm{k}=$ rate constant

This equation indicates that we can determine $\mathrm{k}$ by plotting $\ln [\mathrm{A}]$ versus $t$. The plot must be a straight line, with slope $=-k$, and intercept equal to $\ln [\mathrm{H}]_{0}$.

The field half-life of each herbicide was calculated from equation 1 when the field concentration was equal $[\mathrm{H}]=[\mathrm{H}]_{0} / 2 \mathbf{t}=\mathbf{t}_{1 / 2}$. Therefore, the field half-life is given by equation 2

$$
\mathrm{t}_{1 / 2}=\ln 2 / \mathrm{k}
$$

\section{Data Analysis}

Three replications from each experimental plot were analyzed. Initial herbicide field concentrations were subjected to analysis of variance by using XSTAT software (Addisolf Co., 2005). Initial concentrations of each soil type by year were compared by using Dunnett's test. 


\section{RESULTS AND DISCUSSION}

Table 1 shows climatic data related to monthly rainfall, maximum and minimum temperature and evaporation, from June to October each year. In general, the total rainfall in Fortuna was 6.3 and $22.8 \%$ higher than in Lajas during 1995 and 1996, respectively. In the same way the minimum temperature in Fortuna was 3.9 and $5^{\circ} \mathrm{C}$ higher than in Lajas during the above mentioned years, respectively. Besides, evaporation was much greater in Lajas than in Fortuna. Comparison of field concentration of herbicides on the same day after their application with the soil expected theoretical concentration (SETC) showed that concentrations of prometryn and imazethapyr were not significantly different from their SETC of 1.54 and $0.048 \mathrm{mg} / \mathrm{kg}$, respectively, neither in soils nor years; concentration of oxyfluorfen was significantly different from its SETC of $0.19 \mathrm{mg} / \mathrm{kg}$ only in Fraternidad second year $(\mathrm{F} / 2)$.

The data showed no detectable concentrations of prometryn, oxyfluorfen nor imazethapyr in samples taken from control plots except for oxyfluorfen in the $\mathrm{F} / 2$ treatment. We found in the control plot of $\mathrm{F} / 2$ 0.11 and $0.22 \mathrm{mg} / \mathrm{kg}$ of oxyfluorfen at 28 and 56 days, respectively. This finding was attributed to cross contamination of the samples in the field or during the storage and extraction processes. Comparison of her-

TABLE 1.-Climatological data for Lajas and Fortuna Substations (June 1995 to October 1996).

\begin{tabular}{|c|c|c|c|c|c|c|c|c|c|}
\hline \multirow[b]{3}{*}{ Site } & \multirow[b]{3}{*}{ Month } & \multicolumn{2}{|c|}{$\begin{array}{c}\text { Rainfall (em) } \\
\text { Year }\end{array}$} & \multicolumn{4}{|c|}{$\begin{array}{c}\text { Temperature }\left({ }^{\circ} \mathrm{C}\right) \\
\text { Year }\end{array}$} & \multicolumn{2}{|c|}{$\begin{array}{c}\text { Evaporation }(\mathrm{cm}) \\
\text { Year }\end{array}$} \\
\hline & & \multirow[t]{2}{*}{1995} & \multirow[t]{2}{*}{1996} & \multicolumn{2}{|c|}{1995} & \multicolumn{2}{|c|}{1996} & \multirow[t]{2}{*}{1995} & \multirow[t]{2}{*}{1996} \\
\hline & & & & Max & Min & Max & Min & & \\
\hline \multirow[t]{7}{*}{ Lajas } & June & 9.95 & 7.85 & 33.3 & 19.4 & 32.2 & 17.8 & 10.18 & 8.63 \\
\hline & July & 6.90 & 7.50 & 33.9 & 19.4 & 33.3 & 17.8 & 11.35 & 8.48 \\
\hline & Aug & 13.85 & 12.68 & 33.3 & 18.9 & 32.7 & 17.8 & 11.35 & 11.05 \\
\hline & Sept & 9.25 & 7.43 & 33.3 & 18.9 & 32.7 & 17.8 & 10.35 & 9.28 \\
\hline & Oct & 5.10 & 7.25 & 33.9 & 17.2 & 33.3 & 16.7 & 9.03 & 10.15 \\
\hline & Total & 45.05 & 42.70 & & & & & & \\
\hline & Avg. & 9.00 & 8.55 & 33.3 & 18.3 & 32.7 & 17.8 & 10.45 & 9.53 \\
\hline \multirow[t]{7}{*}{ Fortuna } & June & 1.80 & 5.58 & 32.7 & 23.9 & 32.2 & 23.3 & 5.20 & 5.60 \\
\hline & July & 8.15 & 6.78 & 33.3 & 23.9 & 32.7 & 23.9 & 5.93 & 5.73 \\
\hline & Aug & 19.70 & 13.05 & 33.3 & 23.3 & 32.7 & 23.3 & 5.63 & 5.98 \\
\hline & Sept & 12.55 & 17.05 & 32.2 & 22.8 & 32.2 & 22.2 & 6.50 & 5.85 \\
\hline & Oct & 5.68 & 9.98 & 32.2 & 22.8 & 32.2 & 22.2 & 5.43 & 5.85 \\
\hline & Total & 47.88 & 52.43 & & & & & & \\
\hline & Avg. & 9.58 & 10.48 & 32.7 & 22.2 & 32.2 & 22.8 & 5.68 & 5.83 \\
\hline
\end{tabular}


bicide concentration between soils and years showed no significant difference for prometryn nor imazethapyr; however, for oxyfluorfen, F/2 was significantly higher, probably because of carryover from the previous oxyfluorfen treatment since oxyfluorfen residues were found in the control plot of $\mathrm{F} / 2$ (Table 2).

The Fraternidad soil was slightly acid, with $41 \%$ of clay (Table 3 ) dominated by smectite, a 2:1 mineral (USDA, 1979). The San Antón soil was a nearly neutral, with $28 \%$ of clay (Table 3 ), which has a mixed (2:1 and 1:1) mineralogy (USDA, 1979). The 2:1 clay has more adsorptive surface than 1:1 clay and provides interlayer surfaces that may protect either organic and inorganic compounds of appropriate size such as atrazine (Laird et al., 1992). Ainsworth et al. (1987) have found that weak basic pesticides (base and conjugated acid) are adsorbed as interlayer complexes in smectites (Kennedy, 2003). Therefore, all these conditions enhance oxyfluorfen adsorption in Fraternidad as compared to that in San Antón (Table 3) especially considering that Fraternidad has higher clay content (41\%) than San Antón (28\%), and since oxyfluorfen has a very high $\mathrm{K}_{\mathrm{oc}}$ value and low solubility in water, both must promote its adsorption over soil surfaces such as clay, soil organic matter (SOM) and clay-SOM complexes (Tables 3 and 4).

The percentages of herbicide losses after 28 days of the soil treatment for first and second year, respectively, were in San Antón, 83 and $100 \%$ for prometryn, 36 and $57 \%$ for oxyfluorfen, and 86 and $94 \%$ for imazethapyr; whereas in Fraternidad the percentages of herbicide loss were 51 and $75 \%$ for prometryn, 0 and $45 \%$ for oxyfluorfen, and 62 and $99 \%$ for imazethapyr, respectively (Table 2 ). Our findings showed that herbicides had lower dissipation after 28 days in Fraternidad than in San Antón, and also that prometryn and imazethapyr had an accelerated dissipation after only 28 days of field application, whereas oxyfluorfen was more stable.

Table 5 shows kinetic data and field half-life of the selected herbicides. Lineal correlations were obtained for all treatments except for prometryn second year in San Antón (SA/2). Prometryn SA/2 showed a very fast dissipation reaching no detectable levels 28 days after application. However, the field half-life of prometryn $\mathrm{SA} / 2$ was estimated anyway by using a two-point plot. Half-lives of between two and 43 days for prometryn, 31 and 88 days for oxyfluorfen, and 19 and 46 days for imazethapyr were obtained in our study. No significant differences were observed between soils for pesticide field half-life, neither in the first year treatments nor for oxyfluorfen in the second year. However, significant differences were observed between soils for prometryn and imazethapyr half-life in the second year treatments. Differences in half-life between first and second year treatments for prometryn and 
TABLE 2.-Concentrations of prometryne, oxyfluorfen and imazethapyr remaining in San Antón (SA) and Fraternidad (F) soils after their application in two consecutive years. ${ }^{1}$

\begin{tabular}{|c|c|c|c|c|c|}
\hline \multirow[b]{2}{*}{ Soil/year } & \multicolumn{5}{|c|}{ Days after herbicide application } \\
\hline & 0 & 28 & 56 & 112 & 168 \\
\hline & \multicolumn{5}{|c|}{ Prometryn (mg/kg) } \\
\hline $\mathrm{SA} / 1^{2}$ & $1.35(0.60) \mathrm{a}^{3}$ & $0.24(0.07)$ & $0.03(0.01)$ & $\mathrm{ND}^{4}$ & ND \\
\hline $\mathrm{SA} / 2$ & $1.38(0.51) \mathrm{a}$ & ND & ND & ND & ND \\
\hline $\mathrm{F} / 1$ & $2.16(0.51) \mathrm{a}$ & $1.07(0.36)$ & $0.20(0.07)$ & $0.005(0.006)$ & ND \\
\hline \multirow[t]{2}{*}{$\mathrm{F} / 2$} & $2.73(1.09) \mathrm{a}$ & $0.68(0.19)$ & $0.79(0.06)$ & $0.223(0.093)$ & $0.13(0.03)$ \\
\hline & \multicolumn{5}{|c|}{ Oxyfluorfen (mg/kg) } \\
\hline $\mathrm{SA} / 1$ & $0.13(0.04) \mathrm{a}$ & $0.06(0.01)$ & $0.053(0.013)$ & $0.013(0.005)$ & ND \\
\hline $\mathrm{SA} / 2$ & $0.24(0.02) \mathrm{a}$ & $0.16(0.09)$ & $0.140(0.036)$ & $0.050(0.037)$ & $0.06(0.04)$ \\
\hline $\mathrm{F} / 1$ & $0.28(0.10) \mathrm{a}$ & $0.16(0.04)$ & $0.068(0.021)$ & $0.010(0.008)$ & ND \\
\hline \multirow[t]{2}{*}{$\mathrm{F} / 2$} & $0.76(0.12) \mathrm{b}$ & $0.77(020)$ & $0.330(0.087)$ & $0.090(0.050)$ & $0.12(0.03)$ \\
\hline & \multicolumn{5}{|c|}{ Imazethapyr (mg/kg) } \\
\hline $\mathrm{SA} / 1$ & $0.037(0.008) \mathrm{a}$ & $0.005(0.001)$ & $0.005(0.004)$ & $0.001(0.002)$ & ND \\
\hline $\mathrm{SA} / 2$ & $0.063(0.004) \mathrm{a}$ & $0.004(0.007)$ & $0.007(0.006)$ & $0.005(0.002)$ & $0.005(0.001)$ \\
\hline $\mathrm{F} / 1$ & $0.036(0.012) a$ & $0.014(0.009)$ & $0.004(0.005)$ & $0.004(0.005)$ & ND \\
\hline $\mathrm{F} / 2$ & $0.058(0.018) a$ & $0.001(0.001)$ & $0.013(0.017)$ & ND & $0.008(0.010)$ \\
\hline
\end{tabular}

${ }^{1}$ Mean followed by standard deviation of triplicate measurements.

${ }^{2} \mathrm{SA}=$ San Antón and F = Fraternidad; for example, SA/1 = SA series year one.

${ }^{3}$ Measurements with different letters in the first column for each herbicide are significantly different at $\alpha=0.05$ level of significance by using Tukey' test.

${ }^{4} \mathrm{ND}$-non detectable 
TABLE 3.-Physico-chemical properties of San Antón and Fraternidad soils ${ }^{1}$.

\begin{tabular}{|c|c|c|c|c|c|c|c|}
\hline \multirow[b]{2}{*}{ Soil Type } & \multirow[b]{2}{*}{ Soil order } & \multirow[b]{2}{*}{$\mathrm{pH}$} & \multirow{2}{*}{$\begin{array}{c}\text { CEC } \\
(\mathrm{cmol} / \mathrm{kg})\end{array}$} & Sand & Silt & Clay & OM \\
\hline & & & & \multicolumn{4}{|c|}{$(\%)$} \\
\hline San Antón & Mollisols & 7.4 & 29 & 41 & 31 & 28 & 3.1 \\
\hline Fraternidad & Vertisols & 6.3 & 42 & 33 & 26 & 41 & 2.7 \\
\hline
\end{tabular}

${ }^{1}$ All analyses were performed in the Central Analytical Laboratory of the Agricultural Experiment Station in Rio Piedras.

TABLE 4.-Chemical and physical properties of prometryn, oxyfluorfen and imazethapyr'.

\begin{tabular}{lccccc}
\hline Herbicide & $\begin{array}{c}\text { Solubility } \\
(\mathrm{mg} / \mathrm{L})\end{array}$ & $\begin{array}{c}\text { Vapor Pressure } \\
\left(10^{6} \mathrm{~mm} \mathrm{Hg}\right)\end{array}$ & $\begin{array}{c}\mathrm{K}_{\mathrm{oc}} \\
(\mathrm{ml} / \mathrm{g})\end{array}$ & $\mathrm{pK}_{\mathrm{x}}{ }^{2}$ & $\begin{array}{c}\mathrm{t}_{1 / 2}{ }^{3} \\
(\text { days })\end{array}$ \\
\hline Prometryn & 33 & 1.2 & 400 & 9.95 (basic) & 60 \\
Oxyfluorfen & 0.1 & 0.2 & 100000 & -- & 30 \\
Imazethapyr & 200000 & $<0.1$ & 10 & $2.1,3.9$ (acid) & 90 \\
\hline
\end{tabular}

${ }^{1}$ All values from Hornsby et al. (1995).

${ }^{2} \mathrm{X}=$ basic or acid.

sfield half-life in temperate climate.

imazethapyr were probably due to slight differences in climatic conditions that affect herbicide distribution among soil compartments. Residues remaining from first-year treatments were non-detectable for either herbicide after 168 days (Table 2).

Prometryn tended to show higher half-life in Fraternidad than in San Antón because prometryn, a weakly basic herbicide, becomes positively charged when it accepts a proton. Its basic constant $\left(\mathrm{pK}_{\mathrm{b}}\right)$ is given by equation 3 .

$$
\mathrm{pK}_{\mathrm{b}}-\mathrm{pOH}=\log [\mathrm{B}] /[\mathrm{BH}]
$$

Thus the $[\mathrm{B}] /[\mathrm{BH}]$ ratio for San Antón $(\mathrm{pH}=7.4)$ and Fraternidad $(\mathrm{pH}=6.3$ ) is about 22 and 282 , respectively. Therefore, prometryn must be more strongly adsorbed by Fraternidad than by San Antón soil. The above information confirms data from Liu and Cibes-Viade (1973), where prometryn was more strongly adsorbed over Fraternidad than over San Antón. Higher adsorption of prometryn in Fraternidad soil may account for its longer half-life in Fraternidad than in San Antón.

Contrary to lower dissipation of oxyfluorfen in Fraternidad than in San Antón after 28 days, higher field half-lives were observed in San 
TABLE 5.-Kinetic data of prometryn, oxyfluorfen and imazethapyr in San Anton and Fraternidad soils.

\begin{tabular}{llc}
\hline Soil/year ${ }^{1}$ & \multicolumn{1}{c}{$\mathrm{K}^{2}$, day-1 } & $\mathrm{T}_{1 / 2}$, days \\
\hline & \multicolumn{2}{c}{ Prometryn $(\mathrm{mg} / \mathrm{kg})$} \\
$\mathrm{SA} / 1$ & $0.085(0.003)^{3}$ & $8.1(0.3) \mathrm{a}^{4}$ \\
$\mathrm{SA} / 2$ & $0.338(0.014)$ & $2.1(0.1) \mathrm{a}$ \\
$\mathrm{F} / 1$ & $0.076(0.018)$ & $9.6(2.4) \mathrm{a}$ \\
$\mathrm{F} / 2$ & $0.016(0.003)$ & $43.4(9.8) \mathrm{b}$ \\
& \multicolumn{1}{c}{ Oxyfluorfen $(\mathrm{mg} / \mathrm{kg})$} \\
$\mathrm{SA} / 1$ & $0.0198(0.0021)$ & $35(3) \mathrm{a}$ \\
$\mathrm{SA} / 2$ & $0.0084(0.0025)$ & $88(21) \mathrm{b}$ \\
$\mathrm{F} / 1$ & $0.0249(0.0082)$ & $31(12) \mathrm{a}$ \\
$\mathrm{F} / 2$ & $0.0126(0.0027)$ & $57(13) \mathrm{ab}$ \\
& \multicolumn{1}{c}{ Imazethapyr $(\mathrm{mg} / \mathrm{kg})$} \\
$\mathrm{SA} / 1$ & $0.037(0.013)$ & $20(6) \mathrm{a}$ \\
SA/2 & $0.012(0.005)$ & $46(3) \mathrm{b}$ \\
F/1 & $0.037(0.011)$ & $20(5) \mathrm{a}$ \\
$\mathrm{F} / 2$ & $0.027(0.016)$ & $19(2) \mathrm{a}$ \\
\hline
\end{tabular}

${ }^{1}$ Soil/Year = Soil series and first or second year treatment; soil series are SA = San Antón and F = Fraternidad; for example, SA/1 = SA series year one.

${ }^{2} \mathrm{~K}=$ apparent rate constant, $\mathrm{R}$-square values for the lineal trendline were between 0.79 and $0.99,0.57$ and 0.99 , and 0.75 and 0.99 for prometryn, oxyfluorfen and imazethapyr, respectively.

${ }^{3}$ Values in parenthesis are standard deviation.

${ }^{4}$ Measurements with different letters in the same column are significantly different at $\alpha=0.05$ level of significance by using Tukey' test.

Antón. Oxyfluorfen had no significant hydrolysis after 28 days at $\mathrm{pH}$ between 5 and 9 (Worthing and Hance, 1991) all of which may explain its lower dissipation after 28 days in Fraternidad (lower $\mathrm{pH}$ ) than in San Antón. However, after 28 days dissipation was lower in San Antón probably because it had a slightly higher SOM than Fraternidad, and oxyfluorfen has a very high $\mathrm{K}_{\mathrm{oc}}$ value (Table 5).

Field half-lives of imazethapyr were similar, approximately 20 days, except for $\mathrm{SA} / 2$, which was significantly higher. Imazethapyr is highly soluble in water, has a very low $\mathrm{K}_{\mathrm{oc}}$ (Table 4 ), and is rapidly degraded by sunlight (Loux and Reese, 1993; Goetz et al., 1990; Worthing and Hance, 1991). In addition, imazethapyr is transformed into the anionic form at $\mathrm{pH}$ values higher than its $\mathrm{pK}_{\mathrm{a}} \mathrm{s}$; thus repulsive forces between negatively charged soil particles must decrease its persistence. Therefore, short persistence in Fratenidad and San Antón soils is remarkable since both of them have higher $\mathrm{pH}$ than imazethapyr' $\mathrm{pK}_{\mathrm{a}} \mathrm{s}$, and the effect of high temperature and sun irradiation intensifies under a tropical climate (Tables 4 and 5). 
The half-lives reported in temperate climate for prometryn, oxyfluorfen and imazerthapyr are 60,30 and 90 days, respectively (Hornsby et al., 1995). We found that dissipation was two to 30 times faster for prometryn and four to 14 times faster for imazethapyr than those reported in a temperate climate. The oxyfluorfen dissipation was the same or lower than those in a temperate climate. Similar behavior of fast dissipation of atrazine and simazine, both s-triazine herbicides, and the herbicides metolachlor, alachlor and trifluralin, as well as the insecticides endosulfan and chlorpyrifos, was reported by Laabs et al. (2002) in Brazilian soils, and by Liu and Santiago (1991) for ametryn and diuron in two Puerto Rican soils. Laabs et al. (2002) found that dissipation was three to eight times faster for atrazine and four to 14 times faster for simazine than in a temperate climate. Liu and Santiago (1991) found oxyfluorfen would not persist long enough to provide more than one month of weed control in San Antón soil contrary to our findings of half life between 35 and 88 days. However, Liu's experiments were performed in a drip-irrigated banana field, where higher humidity was needed than for pigeon pea fields, all of which explains differences in herbicide dissipation between Liu's experiment and ours.

Our findings have confirmed previous data showing that field half lives of prometryn, oxyfluorfen and imazethapyr greatly differ because they are sensitive to variations in soil type, crop management and climatic conditions (Hornsby et al., 1995). Oxyfluorfen can persist longer than prometryn and imazethapyr under similar conditions. However, in addition to climatic conditions, application and irrigation rate seem to be of prime importance in determining persistence of these herbicides.

\section{LITERATURE CITED}

Ainsworth, C. C., J. M. Zachara and R. L. Schmidt, 1987. Quinoline sorption on Na-montmorillonite: Contributions of the protonated and neutral species. Clays Clay Miner 35:121-128.

Curran, W. S., R. A. Liebl and W. Simmons, 1992. Effect of tillage and application method on clomazone, imazaquin and imazethapyr persistence. Weed Sci. 40:482-489.

Goetz, A. J., T. L. Lavy and E. E. Gbur, 1990. Degradation and field persistence of imazethapyr. Weed Sci. 38:421-428.

Helling, C. S., 1971. Pesticide mobility in soils III. Influence of soil properties. Soil Sci. Soc. Amer. Proc. 35:743-748.

Hornsby, A. G., R. D. Wauchope and A. E. Herner, 1995. Pesticide Properties in the Environment. Springer-Verlag Inc., New York.

Kennedy, M. J., 2003. Interlayer mineral surface area of smectitic clay minerals as an important control of TOC in Balck Shale. Seattle Annual Meeting. Paper No. 19-12.

Laabs, V. W. Amelung, A. Pinto and W. Zech, 2002. Fate of pesticides in tropical soils of Brazil under field conditions. J. Environ. Qual. 31:256-268. 
Laird, D. A., E. Barrisoso, R. H. Dowdy and W. C. Koskinen, 1992. Adsorption of atrazine on smectites. Soil Sci. Am. J. 56:62-67

Levanon, D., J. J. Meisinger, E. E. Codling and J. L. Starr, 1994. Impact of tillage on microbial activity and the fate of pesticides in the upper soil. Water Air Soil Pollution 72:179-189.

Li, J., C. H. Langford and D. S. Gamble, 1996. Atrazine sorption by a mineral soil: Effect of soil size fractions and temperature. J.Agric. Food Chem. 44:3680-3684.

Liu, L.C. and H.R. Cibes-Viade, 1973. Adsorption of fluometuron, prometryn, sencor and 2,4-D by soils. J. Agric. Univ. P.R. 57(4):286-293.

Liu, L. C. and M. Santiago, 1991. Persistence of three herbieides in a drip-irrigated banana field. J. Agric. Univ. P.R. 75(1):19-23.

Loux, M. M., R. A. Liebl and F. W. Slife, 1989. Availability and persistence of imazaquin, imazethapyr and clomazone in soil. Weed Science 37(2):259-267.

Loux, M. M. and K. D. Reese, 1993. Effect of soil type and $\mathrm{pH}$ on persistence and carryover of imidazoline herbicides. Weed Tech. 7(2):452-458.

Nelson, D. W. and L. E. Sommers, 1996. Total carbon, organic carbon and organic matter, p. 995-998. In: D.J. Sparks et al. (Ed.). Methods of Soil Analysis, part 3. Chemical Methods. SSSA Book Ser, 5 SSSA and ASA, Madison, WI.

Oliveira, R. S., W. C. Koskinen and F. A. Ferreira, 2001. Sorption and leaching potential of herbicides on Brazilian soils. Weed Research 41(2):91-110.

Paraíba, L. C., A. L. Cerdeira, E. F. da Silva, J. S. Martins and H. L. da Costa-Coutinho, 2003. Evaluation of soil temperature effect on herbicide leaching potential into groundwater in the Brazilian Cerrado. Chemosphere 53:1087-1095.

Sumner, M. E. and W. P. Miller, 1996. Cation exchange capacity and exchangeable coefficient, p. 1220-1221. In: D.J. Sparks et al. (Ed.). Methods of Soil Analysis, part 3. Chemical Methods. SSSA Book Ser, 5 SSSA and ASA, Madison, WI.

Worthing, C. R. and R. J. Hance, 1991. A World Compedium. The Pesticide Manual. 9th ed. The British Crop Protection Council.

USDA, 1979. Soil Survey of Ponce Area of Southern Puerto Rico. Natural Resources Conservation Service. $80 \mathrm{pp}$.

Ying, G. G. and B. Williams, 2000. Dissipation of herbicides in soil and grapes in a south Autralian vineyard. Agriculture Ecosystems \& Environment 78:283-289.

WSSA, 1989. Herbicide Handbook of the Weed Science Society of America, Herbicide Handbook Committee. 6th Ed. WSSA, Champaign, IL. 